Meta

Journal des traducteurs

Translators' Journal

\title{
Loaves of Bread and Jugs of Wine: Three Translation of Omar Khayyám
}

\section{Scott Jermyn}

Volume 34, numéro 2, juin 1989

URI : https://id.erudit.org/iderudit/003263ar

DOI : https://doi.org/10.7202/003263ar

Aller au sommaire du numéro

Éditeur(s)

Les Presses de l'Université de Montréal

ISSN

0026-0452 (imprimé)

1492-1421 (numérique)

Découvrir la revue

Citer cet article

Jermyn, S. (1989). Loaves of Bread and Jugs of Wine: Three Translation of Omar

Khayyám. Meta, 34(2), 242-252. https://doi.org/10.7202/003263ar d'utilisation que vous pouvez consulter en ligne.

https://apropos.erudit.org/fr/usagers/politique-dutilisation/ 


\section{LOAVES OF BREAD AND JUGS OF WINE : THREE TRANSLATIONS OF OMAR KHAYYAM}

SCOTT JERMYN

Ghiváth al-Dín Abu'l-FAth 'Umar b. Ibrahim al-Khayyámí (as he is named in Arabic sources), or 'Umar-i Khayyám (in Persian sources), was born in Nishápúr, Persia, in 439-1048 and died in 526-1131. ${ }^{1}$ His name means the "tent-maker," and it has commonly been thought that this was the profession of his father or grandfather. During his long life, he established a name for himself as an astronomer and mathematician, but he is also reputed to have written a number of ruba iy át (quatrains). In the Occident, the words rubá iyát and Khayyám have become virtually synonymous because of the immense popularity of Edward FitzGerald's nineteenth century translation, The Rubáiyát of Omar Khayyám. The number of contemporary critics who applauded FitzGerald's translation is staggering and includes Tennyson, Carlyle, Dante Gabriel Rossetti, Swinburne, Ruskin and countless others. In fact, FitzGerald's translation became so popular that his editor proudly remarked that Khayyám would have been an obscure poet in his own native Persia had it not been for FitzGerald. Since FitzGerald brought him to the world's attention, thousands of books and articles have been published on Khayyám. There have also been frequent imitations of FitzGerald's translation, and the quatrains themselves have been constantly retranslated. In addition to FitzGerald, the list of Khayyám's English translators includes the distinguished Orientalist, A. J. Arberry, and the irrepressible poet and critic, Robert Graves, with Omar Ali-Shah. These translators have faithfully rendered, subtly altered, paraphrased, or even transmogrified the quatrains of Khayyám. Moreover, the history of Khayyám's English translators is a controversial one, beset by ignorance, argument, and fraud.

Oddly enough, we are not even sure if Khayyám wrote any poems. It is known that he was a successful astronomer and mathematician, and also a follower of the rationalist philosopher Ibn Síná, but there is no contemporary reference to Khayyám as a poet. In the years after his death, there arose a number of rubá 'iyát that were attributed to him in several sources. By the fourteenth century, this number reached 60 . These ruba' iyat are found in a variety of biographical, theological, and historical sources, making the problem of authentificating individual quatrains extremely difficult. Further complicating the problem is the fact that a number of these poems are found in earlier or later manuscripts under the names of other poets. V. Zhukovsky, who was the first to reveal this problem, called these rubá 'iyat "wandering quatrains." Though there are many manuscripts which contain quatrains attributed to Khayyám, there is no reliable life-time manuscript. For instance, the Ouseley manuscript in the Bodleian Library at Oxford, on which FitzGerald in part based his translation, is one of the earliest extant, but it is dated $865 / 1460$, over three hundred years after Khayyám's death.

Among the plethora of manuscripts, well over a thousand rubá iýát have been attributed to Khayyám, but how many of these attributions are authentic is a much-debated 
matter. In 1934, H. A. Schaeder is reputed to have said that Khayyám wrote nothing and that "his name must be struck out of the history of Persian literature." Most scholars are not so extreme. Among the more reliable estimates, Arthur Christensen puts the number of authentic rubá '́yát at 121; Sadiq Hedayat, 143; Muhammed 'Ali Furughi, 1782; and Ali Dashti regards 75 as authentic and 26 as likely. In the introduction to his new translation of 1952, A. J. Arberry commented that Khayyám probably never wrote a collection of rubá'iyát, rather "He spoke them extemporaneously, as all composers of rubáiyát should do" (43). Such a combination of oral and subsequent written traditions may explain the confusing history of Khayyám's rubá 'íyát, but ultimately, the oftenquoted words of E. G. Brown in 1902 still hold true :

The upshot of the whole inquiry is that, while it is certain that 'Umar Khayyam wrote many quatrains, it is hardly possible, save in a few exceptional cases, to assert positively that he wrote any particular one of those ascribed to him $(2: 257)$.

Early translators of Khayyám were evidently unaware of this problem with authenticity. For instance, in $1867 \mathrm{~J}$. B. Nicolas translated into French 464 quatrains, few of which are now considered authentic. Zhukovsky showed that no less than 82 of the quatrains in Nicolas' translation are found in the divans of 39 other poets (360-361). Subsequent scholars have raised this number of "wandering quatrains" even higher. Nicolas' contemporary, FitzGerald, was also indiscriminate in his use of manuscripts. But it was not FitzGerald's intention to make an exact translation (which he freely admitted), and he undoubtedly would have been unconcerned to find that the manuscripts he used were apocryphal. There have been more recent translations, such as Arberry's and Graves', which have attempted to remain faithful to the original Persian rubá' 'yát, but there has never been complete accord among scholars on which of the original rubá íyát are authentic.

The story behind the early success of Edward FitzGerald's translation is wellknown. Dante Gabriel Rossetti discovered the poorly-selling, anonymous first edition in a bin of books at reduced prices and purchased it for a penny. Rossetti introduced the translation to his friend Swinburne, and soon thereafter, when the first edition sold out, a call went out from the increasing number of satisfied readers for another edition. John Ruskin's reaction to FitzGerald's translation echoes the sentiment of the day:

I do not know in the least who you are, but I do with all my soul pray you find and translate some more of Omar Khayyam for us: I never did - till this day - read anything so glorious, to my mind as this poem ... and that, and this, is all I can say about it. - More more - please more. (Terhune, Life, 212)

In all, FitzGerald produced five editions; each is marked by revision, as the first quatrains of these editions attest. The version in the first edition is closest to the Persian original:

Awake! for Morning in the Bowl of Night

Has flung the Stone that puts the Stars to Flight;

And Lo! the Hunter of the East has caught

The Sultan's Turret in a Noose of Light. 
The second edition reads :

Wake! For the Sun behind yon Eastern height

Has chased the Session of the Stars from the Night

And, to the field of Heav'n ascending, strikes

The Sultan's Turret with a Shaft of Light.

The third edition changes the first two lines:

Wake! For the Sun before him into Night

A signal flung that put the Stars to flight.

The fourth and identical fifth provide another revision:

Wake ! For the Sun, who scatter'd into flight

The Stars before him from the Field of Night,

Drives Night along with them from Heav'n and strikes

The Sultan's Turret with a Shaft of Light.

In the introduction to his more literal translation, Arberry rendered Khayyám's quatrain as follows:

The sun the noose of morning upon the roof has cast,

the emperor of day the pebble into the cup has cast;

drink wine, for the proclamation of Love at the

time of dawn

the cry "Drink ye !" among the days has cast. (18)

Swinburne found only the first version agreeable and spurned the later editions of FitzGerald's translation, but many other readers have found the later editions better crafted and more felicitously phrased. Questions of esthetic superiority notwithstanding, FitzGerald's translation clearly became more "creative" as he progressed in his editions. In a letter, he wrote :

I suppose very few People have ever taken such Pains in Translation as I have : though certainly not to be literal. But at all Cost, a Thing must live: with a transfusion of one's own worst Life if one can't retain the Original's better. Better a live Sparrow than a stuffed Eagle. (Terhune, Letters, $2: 335$ )

The question of how much of FitzGerald's life was transfused into the original has troubled a number of scholars. Edward Heron-Allen first established the degree of FitzGerald's reliance on the Persian original in 1899, in a balanced, scrupulous examination that remains a valuable source for scholars and translators. ${ }^{3}$ In particular, HeronAllen broke down the 101 quatrains of FitzGerald's fourth edition as follows:

Of Edward FitzGerald's quatrains, forty-nine are faithful and beautiful paraphrases of single quatrains to be found in the Ouseley or Calcutta MSS, or both.

Forty-four are traceable to more than one quatrain, and may therefore be termed the "composite" quatrains.

Two are inspired by quatrains found by FitzGerald in Nicolas' text.

Two are quatrains reflecting the whole spirit of the original poem.

Two are traceable exclusively to the influence of the Mantik ut-tair of Ferid ud Din Attar.

Two quatrains primarily inspired by Omar were influenced by the Odes of Hafiz. 
And three, which appeared only in the first and second editions and were after wards suppressed by Edward FitzGerald himself, are not - as far as careful search enables me to judge - attributable to any lines of the original texts. (xi-xii)

Though FitzGerald was not faithful to the content of his source, he did bring to his translation several important innovations that are now famous. The most important of these innovations is the structure that he superimposed upon the original. A Persian collection of rubálýt, a divan, does not make up a unified whole; it is not one poem of many stanzas. It was FitzGerald's intention, however, to write a single poem in stanzaic form. To unify the unconnected rubályát of the original, FitzGerald began his translation with a description of the rising of the sun and concluded it with the rising of the moon. During the course of this single day, Khayyarm meditates on God and life, all the while drinking wine.

FitzGerald himself stated a number of times that his translation was not perfectly faithful nor was it necessarily meant for those who understand Persian. Instead, in his preface to the second and third editions, he wrote:

Those [quatrains] here selected are strung into something of an Eclogue, with perhaps a less than equal proportion of the "Drink and make-merry," which (genuine or not) recurs overfrequently in the Original. Either way, the Result is sad enough : saddest perhaps when most ostentatiously merry : more apt to move Sorrow than Anger toward the old Tent-maker, who, after vainly endeavoring to unshackle his Steps from Destiny, and to catch some authentic Glimpse of TO-MORROW, fell back upon TO-DAY (which has outlasted so many To-morrows !) as the only Ground he got to stand Upon, however momentarily slipping from under his Feet. (36)

In order to fulfill his goal of creating what he called an "Epicurian Ecloque in a Persian Garden" (Terhune, Letters, $2: 323$ ), FitzGerald did not translate any quatrains in the original that revealed a more pietistic strain in Khayyám. FitzGerald rightly felt such quatrains would disrupt the tone of his melancholy, hedonistic sequence. Also, in typically Victorian fashion, FitzGerald bowlderized the especially irreverent and ribald rubá '́yát.

Though he took great liberties with the structure and content of his translation, surprisingly FitzGerald retained the rhyme scheme of the original (aaba and sometimes aaaa). Since it probably would have been impossible to imitate the meter of the rubá $i$ in English, FitzGerald did not attempt to do so and instead wrote a very successful iambic pentameter line. By retaining the Persian rhyme scheme, he intended to capture the flavor of the original Persian. In a letter to his friend, Edward Cowell, who helped with the translation, FitzGerald explains,

I am more \& more convinced of the Necessity of keeping as much as possible of the oriental Forms, \& carefully avoiding anything that brings back Europe and the nineteenth century. It is better to be orientally obscure thant Europeanly clear. (Arberry, FitzGerald's Salámán, 46)

In addition to the Persian rhyme scheme, FitzGerald retained a number of terms, such as "Ferrásh," "Sákí," and "Tamám," from the original. Although obscure to the nonMuslim, these terms are all part of a "fugitive articulation" of Victorian despair. In a sense then, the poem tells us more about Victorian sceptics than Muslim. By retaining the Oriental flavor of the original, FitzGerald distances himself from his composition, as if to say that these are exclusively Khayyám's words and not his own and that Khayyám must take the blame for the heterodox views espoused in the work. The oriental obscurity in the translation results in part from his concern for himself, as well as from his latent 
concern for fidelity to the original. It is no coincidence that FitzGerald's first edition was published anonymously and that the fourth edition was published with his translation of the Sufi Jami's pietistic Salámán and Absal. Though FitzGerald apparently masked his own doubts and distanced himself from his source, his letters show that he had an affinity for the scepticism of Khayyám. Ultimately, FitzGerald must take some of the blame - or credit - for the heterodox views of his translation. Many of the original rubá iyát are comic and half-serious in tone; the transfusion of FitzGerald's own life into his translation makes his quatrains more dismal and melancholy.

Khayyám's heterodox proclamations are extensive. Throughout the poem, he constantly questions the ways of God. In particular, FitzGerald's Khayyám sees the human race as,

But Helpless Pieces of the Game He plays

Upon this Chequer-board of Nights and Days :

Hither and thither moves, and checks, and slays,

And one by one back in the Closet lays. (LXIX) ${ }^{4}$

In the poem, Khayyám's questions are ubiquitous. If God creates beautiful things, then why does he destroy them? Why did God create man for this pointless existence on earth? And why did God create wine, if it is forbidden to man, or specifically Muslims?

Why, be this Juice the growth of God, who dare

Blaspheme the twisted tendril as a Snare?

A Blessing, we should use it, should we not?

And if a Curse - why, then, who set it there? (LXI)

Wine is the one comfort that FitzGerald's Khayyám has to assuage his fears. FitzGerald's translation is so replete with passages extolling wine that FitzGerald himself has been accused of hedonism. While this charge is certainly untrue, his Khayyám is undoubtedly a hedonist, who is also occasionally witty and always intelligent. The obvious erudition of Khayyám encompasses a vast range of subjects. Ultimately, FitzGerald's Khayyám emerges as something of a despairing intellectual and philosopher.

For all of FitzGerald's liberties in translation, the Eastern flavor of the original is always retained. Most Orientalists would probably agree that FitzGerald captured the spirit, if not the substance, of his Muslim predecessor. Peter Avery, for instance, remarked that "FitzGerald showed an almost uncanny insight, an instinctive capacity to put himself in the place of a medieval Persian sceptic" (x). While FitzGerald's Khayyám represents something of a paradigm for the undercurrent of religious doubt in the medieval Islamic world, he is also representative of the sceptic in any age or culture. FitzGerald's Khayyám is simply a character in a poem. He has an historic or literary prototype, but it is not appropriate to look at FitzGerald's Khayyám as a legitimate medieval Persian. Furthermore, FitzGerald's Persian poem contains a number of anachronisms that identify the author as a Victorian Englishman, or at least a post-medieval European.

Ultimately, FitzGerald's Khayyám is more representative of Victorian England than medieval Persia. In FitzGerald's later editions, Khayyám and his language become increasingly less "orientally obscure" and more conventionally Victorian. The first edition, for instance, mentions the "orientally obscure" custom of casting a pebble into a cup, signalling the breaking of camp. The second edition excises these lines in favor of a more conventional image of the sun chasing the stars from the sky. Since the poem incorporates such a large range of Victorian tastes, "the Rubáiyát is perhaps the archetypical Victorian poem" (Schenker 61). Though the point should not be exaggerated, 
FitzGerald's translation is probably the age's finest representative of the spirit of doubt. As such, FitzGerald's agnostic Rubáiyát is perhaps best seen as an answer to Tennyson's ultimately faithful In Memoriam. Together, they best represent the paradox of the overtly religious age of Victoria. It was the age of the 39 articles of the Church of England, but it was also an age in which Matthew Arnold heard the "melancholy, long, withdrawing roar" of the "sea of faith," and on the continent, Friedrich Nietzsche proclaimed God to be dead. FitzGerald's poem is part of the vast Victorian undercurrent that doubted.

In 1952, Arthur J. Arberry published a new translation of 252 ruba iyat, based on the discovery of two new manuscripts in Tehran. Arberry did not intend to "improve" upon FitzGerald's translation: "it would be gross impertinence, and would betray a singular perversity of taste to make the attempt - to belittle the greatness of a Victorian genius" (42). Instead, Arberry wanted to present a more complete picture of Khayyám, to avoid the unidimensional portrait of FitzGerald's loose paraphrase. The two manuscripts on which Arberry bases his translation were dated within a century after the death of Khayyám $(604 / 1207$ and $658 / 1259)$. If legitimate, these manuscripts would predate FitzGerald's source, the Ouseley manuscript, by over two hundred years and would be the oldest manuscripts in existence.

Unfortunately, both manuscripts are now considered to be forgeries. Soon after Arberry published his translation, there appeared in Tehran two more manuscripts. The discovery of these manuscripts raised the suspicion of a number of scholars, Arberry among them, who doubted the authenticity of all four of the new manuscripts, but it was not until 1967 that V. M. Minorski established conclusive proof of the forgery. Minorski made a detailed analysis of the rubá 'iyát found in the manuscripts that Arberry used for his translation and decided that the source for the forgery was F. Rosen's edition of 329 quatrains. 5 The manuscript that Rosen used for his translation was considered to be untrustworthy even before Arberry attempted his own translation. Ironically, in the introduction to his translation, Arberry himself stated that the antiquity of Rosen's manuscript was questionable (9). And, in a chart listing the rubá íyát of his translation and their occurrences in other manuscripts, Arberry showed that only 13 of the quatrains in his translation are not in Rosen's edition. Arberry's apocryphal manuscripts remain a great disappointment, but Minorski points to a valuable lesson to be learned: "we have now to keep in mind the evidence about the activities in Tehran of a group of able calligraphers eager to supply the market for antiquities by their forgeries" (117).

Yet there is a benefit to examining Arberry's translation of the forged manuscript, even if it cannot give us a precise, reliable understanding of the actual, historical Khayyám. Like FitzGerald's translation, Arberry's gives the modern reader a glimpse into the mind of a medieval Persian sceptic, but the picture that Arberry presents is more sophisticated and accurate. In translating the Persian manuscript, Arberry limited himself to a literal rendering of the original, and where he does deviate from the original he gives a note of explanation. Unlike FitzGerald, Arberry did not rearrange the order of the manuscript's rubá'íyát, but he did change the original Persian rubá $i$ into two four-line stanzas in iambic tetrameter with a rhyme scheme of $a b b a$, as in Tennyson's In Memoriam. His sixty-sixth poem, for example, is a literal verse translation of the rubá $i$ that FitzGerald used for the first quatrain of his translation:

The sun has cast the noose of morn

Athwart the roof-top of the world;

The emperor of day has hurled

His bead, our goblet to adorn. 
Drink wine : for at the first dawn's rays

The proclamation of desire

Rang through the universe entire,

And bade men drink through all the days.

Arberry's Khayyám is not unidimensional like FitzGerald's hedonist, but there are still a great number of rubá 'íyát dealing with the virtues of drinking wine. Arberry warns us, however, not to take the indictment of hedonism too seriously. He contends that Khayyám was parodying the traditional themes of the rubá $\imath$, love and piety. Indeed, Arberry even contends that the overall mood of the collection is one of "gay cynicism" (43). Unlike FitzGerald's translation, the apparent hedonistic passages are written primarily for comic effect. For instance, Khayyám asserts that he will drink until his "rounded paunch" will make him look like a vat of wine (110). Citing an old proverb that Truth is "bitter stuff," Khayyám asserts that wine must also be "right and proper" since it also is bitter (248). Khayyám tells us to never fall into grief because of the vicissitudes of fortune. "Nor live one moment without wine" (20). More than once Khayyám expresses the sentiment that "Rank poison is the world's distress, / And the sole antidote is wine" (221). In the final poem of the collection, Khayyám prays to the Lord to have mercy, compassion and forgiveness for he has visited the "inviting tavern," but he also prays that God "take my goblet not away" (252).

These quatrains can hardly be taken seriously, and Khayyám's "hedonism" is certainly mitigated by the tongue-in-cheek tone of the poems. Also, in his introduction, Arberry speaks of the abundance of "academic jokes" in the manuscript he translated (34). Indeed, reading through his translation, it is easy to pick out the various quips. For example, Arberry identifies the sixty-third poem as a "good mathematical jest":

Now with a glass one measure high

Grief I will slay, old foe of mine,

And, having quaffed two pints of wine,

Count no man half as rich as I.

First, in divorce thrice over cried, Reason and Faith I'll put away,

Then take, to crown my happy day,

The daughter of the grape for bride.

In Islam, Divorce is instituted by crying out "I divorce you" three times. Arberry points out that his poem bears comparison to the famous fifty-fifth quatrain of FitzGerald's translation, but the word-play is more sophisticated in Arberry's faithful rendering of the original Persian. It is possible that FitzGerald simplified his translation of the ruba $i$ because he missed the point of the original quatrain, or he may have been compelled to simplify his version because his four-line stanza could not gracefully accommodate the sophistication of the original.

Arberry identifies an impressive topical range parodied by Khayyám. The range of topics includes cosmology (218), physics (76), mystics (11,219, and passim), theologians or moralists (222 and 238), and theology itself, for instance the doctrine of the eternity of the world (149). Ultimately, Arberry refuses to identify more: "I will not be so inconsiderate as to rob my readers, if they so choose, of all the fun" (37). Arberry's ironic choice of the In Memoriam stanza adds to the general tongue-in-cheek tone of these poems. Though the stanza is almost universally associated with the elegiac mood of Tennyson's poem, Arberry felt that the tetrameter approximated the "natural lightness and informality of the Persian rhythm" (45). Though Arberry understandably does not handle the quatrain with the same facility of Tennyson, the meter does in fact work quite well in capturing the 
witty, epigrammatic feel of the Persian rubá $i$ and adds significantly to the overall light, almost satiric, mood of the translation.

In the midst of these comic quatrains are a number of radically irreverent blasphemies. For instance, in the second rubá $i$ of the collection, Khayyám blasphemously uses the name of Burák, the horse on which Muhammed is believed to have made his journey to heaven, although Arberry euphemistically refers to the animal as "speculation's steed." In the eighteenth quatrain, Khayyám states that instead of dedicating the month of Ramadan to God, he dedicates that month to drinking. The "Night of Power," a typically sacred time for Muslims on the 27th of Ramadan, is specifically dedicated to drinking (201). In quatrain 88 , Khayyám, upset at having dropped his cup of wine, blames God and asks if the cruel Lord is drunk. It is a mark of the difference between FitzGerald's and Arberry's translations that FitzGerald repressed this last quatrain in his translation, apparently because of its impiety. There are many examples of Khayyám's radical heterodoxy in Arberry's translation; and, though some critics would like to make Khayyám more religious than he appears, ultimately, there can be no real defense of the blasphemous poems. In essence, the questions posed by Arberry's Khayyám are much the same as those posed by FitzGerald's, though they are occasionally more vituperative and almost always more witty.

In Arberry's translation, there are also a number of the "pious" quatrains which FitzGerald repressed in his translation. There is, for instance, the quatrain believed to have been recited by Khayyám on his death-bed:

Lord, I am weary unto death

Of this mean being that is mine:

The fetters that my heart confine,

My empty hands, my narrow breath.

Yet Thou hast power to transmute

The naughted unto entity:

$O$ raise me to the sanctuary

Of Thine Being Absolute. (213)

Arberry suggests several theories why a handful of pietistic poems should surface among such a consistently unorthodox collection. Some believe that Khayyám was merely trying his hand at a theme ubiquitous in literature - that of obedience to God. Others believe that, later in life, Khayyám foresook his hedonism and became the serious writer of these "pious" quatrains. It is also possible that Khayyám did not write any of these "pious" poems at all; rather they are merely a number of "wandering quatrains."

Arberry's translation is not a definitive collection of Khayyám's verse. It is closer to an anthology of medieval Persian verse. Like FitzGerald's translation, it does not teach us much about Khayyám himself, but it can teach us some things about medieval Persian culture: in the diversity of the themes of the rubá iyat it it represents a large cross-section of that society. There were probably many writers of the rubá iy át Arberry translated, and no one motif or tone is sustained by all of them. What really distinguishes Arberry's translation is the overall impression of Khayyám as a paragon of the sophisticated, Muslim comic cynic. It is this comic genius that assuages the indictments of hedonism and heresy. The main difference between Arberry's and FitzGerald's translations lies in mood, a difference best seen in the passages dealing with wine. In Arberry's translation, the wine passages are considerably more humorous, and perhaps even more harmless, than the despairing hedonistic passages in FitzGerald's translation. Whereas FitzGerald interpreted Khayyám as a pitiful, hedonistic "old Tent-maker," Arberry saw him as a "rationalist Pessimist" with a fine sense of humour (27). Ultimately, the overall picture of 
Arberry's Khayyám as a "gay cynic" is an amazing, and more accurate, counterpart to the dismal, hedonistic Khayyám of FitzGerald's translation.

In 1967, Robert Graves and Omar Ali-Shah published their translation of Khayyám. According to the authors, the translation was made from a manuscript of "uncontradictible authority" dated 1153 A.D. and in the possession of Ali-Shah's family. Ali-Shah translated this manuscript into a literal prose "crib" which Robert Graves versified. If the date is to be trusted, this manuscript would represent the oldest extant collection of Khayyámic verse. In "critical commentaries" accompanying their translation, Graves and Ali-Shah attacked their two most important predecessors: FitzGerald and Arberry. Ali-Shah denied the validity of Arberry's manuscripts and did not include them in a list of manuscripts of Khayyám's rubá 'íyát, though the list included the forgeries' principal source, Rosen's manuscript. Ali-Shah also took Arberry to task for having mistranslated some rubá'íyát, and Graves wrote long, critical passages in his introduction chastising FitzGerald for mistranslating and misunderstanding Khayyám. Graves and AliShah promised a literal word-for-word and line-by-line translation. They assured their readers that their four-line stanzas were exact English reproductions of the original Persian rubáíyát.

By 1968 , several scholars proved the new translation to be a fraud. L. P. ElwellSutton, in "The Omar Khayyam Puzzle," showed that the new translation was in fact copied out of Heron-Allen's analysis of FitzGerald's first edition. Heron-Allen gave a literal translation of those quatrains which FitzGerald earlier used and put these in a purely arbitrary sequence. The Graves/Ali-Shah translation follows this sequence faithfully. Subsequently, Elwell-Sutton and J. C. E. Bowen revealed that many errors Heron-Allen made in his translation were reproduced in the new versified translation. Also, contrary to Ali-Shah's statement that he spoke "Classical Persian" as a child, these scholars questioned whether Ali-Shah knew much Persian at all. For instance, Elwell-Sutton in "The Rubaiyat Revisited" discusses some of the thirty-one errors discovered in the transcription and translation of just two of the rubá iyát that were included in the Graves/Shah translation (182). Finally, in 1969 Bowen went to Afghanistan to try to locate the original manuscript in order to determine whether there was any truth to Ali-Shah's story of a manuscript of "uncontradictible authority." He could find nothing. 6

Of course, Graves and Ali-Shah denied all accusations of fraud, and on the merit of Graves' reputation as a poet, their translation soon gained popularity. Also, the authoritarian tone that Graves and Ali-Shah used in their introductory commentaries convinced many readers of the translation's validity. For instance, in a 1970 edition of FitzGerald's translation published by the Folio Society, an anonymous editor apologetically advises his readers to see the Graves / Shah translation for a more accurate rendition of Khayyám. No advice could be worse. The content of the Graves/Shah translation is much the same as FitzGerald's. Even the sequences of the poems in the two translations are nearly identical, since the Graves / Shah translation copied Heron-Allen's study which in turn roughly followed FitzGerald's sequence of poems. This sequence alone should tell any scholar that the Graves / Shah translation is questionable since a divan is a thematically unconnected collection of poems: it is virtually impossible that a twelfth-century Persian manuscript could anticipate the order of rubá 'iyát in Heron-Allen's study or FitzGerald's poem. But the authors, apparently oblivious to this fact, ludicrously praised the climactic structure of their translation and chastised FitzGerald for superimposing his own structure on the original.

One thing at least is certain : FitzGerald's translation is far superior in esthetic quality. Yet, in perversely vituperative passages, Graves attacks his predecessor for ruining 
the artistic quality of the original. For instance, Graves and Ali-Shah list FitzGerald's popular twelfth quatrain in the back of their book:

A Book of Verses underneath the Bough,

A Jug of Wine, a Loaf of Bread, and Thou

Beside me singing in the Wilderness -

Oh, Wilderness were Paradise enow!

then they list what they consider to be their own more successful thirteenth quatrain :

Should our day's portion be one mancel loaf,

A haunch of mutton and a gourd of wine

Set for us two alone on the wide plain,

No Sultan's bounty could evoke such joy.

Few commentators would agree with Graves that he has improved much on FitzGerald's version of the poem. Also, Graves' quatrain is riddled with errors. Instead of accuracy and eloquence, we have an inaccurate translation that, far from being esthetically superior to FitzGerald's poem, seldom approaches poetry itself.

Ultimately, the only remarkable thing about the Graves/Shah translation is the fact that the authors claim that Khayyám was a Sufi. This idea is hardly a new one: many scholars have attempted to interpret the passages about wine as Sufi symbols. In Sufi symbolism, wine is representative of the intoxicating joy of union with God. In his French translation, J. B. Nicolas, FitzGerald's contemporary, contended that Khayyám was a Sufi, but in the preface to his fourth edition, FitzGerald disagreed with Nicolas' interpretation. He rightly felt that there was no historical proof that Khayyám was a Sufi. A more recent and authoritative scholar, Ali Dashti, comments that "we can say with some certainty that Khayyam fell into that rare category of people who are not prepared to take a definite stand in the matter of religion" (97). Moreover, FitzGerald pointed out that Khayyám's hedonistic passages are far too materialistic to be considered symbolic, and the language that FitzGerald uses in his introduction insists that the apparent hedonism is symbolic, but neither Graves' poems nor his commentary is very convincing. As Arberry put it, "the most superficial perusal of Omar's poems makes it abundantly clear that he was no friend of the Sufis, whom he both parodies and directly attacks in a number of places" (1952: 27).

The pietistic tone of Graves' Khayyám suffers not only in comparison to FitzGerald's but also to Arberry's translation. Graves' Khayyám is lifeless, uninteresting, and painfully pious in comparison to Arberry's humorous Khayyám. Ultimately, there can be no legitimate glimpse into the medieval Persian mind by interpreting Khayyám as a pious Sufi, at least not in the rubályát that FitzGerald, Arberry, or Graves and Ali-Shah translated. Among the three translations here examined, it is only the predominant image of Khayyám as a "gay cynic" in Arberry's translation that emerges as a unique archetype of a medieval Persian, but even here the image is incomplete. There is not, and perhaps never will be, a definitive collection of Khayyám's verse. We must be content to piece together those rubá iyát found in various manuscripts which seem authentic with those rubá'iyát which seem to be the type of poems that Khayyám would write, but no one has been completely successful in this endeavor. 
Notes

1. Throughout this essay, the dates are given first by the Muslim and then by the Gregorian calendar. Muslims begin their era with the Hijra of Muhammad from Mecca to Medina in 622 A.D., called Annon Hegirae. Khayyám's birth date was established convincingly by Govinda Tirtha. The date of his death, however, is not always agreed upon, and the date on his tombstone reads $516 \mathrm{AH}$.

2. The selection of Hedayat and that of Furughi with Qasin Ghani have recently been translated by Peter Avery and John Heath-Stubbs.

3. A. J. Arberry's Romance of the Rubáiyát is an invaluable quide to how FitzGerald translated the poems. Arberry provides extensive annotations for all the quatrains of the first edition.

4. This an all subsequent references to FitzGerald's translation are to the fifth edition.

5. First published in a Persian edition in 1925 and in an English translation in 1930.

6. For a summary discussion of the whole affair, see Bowen's Translation or Travesty? or "The Ruba"iyyat of Omar Khayyam : A Critical Assessment."

\section{WORKS CITED}

ARBERRY, Arthur J. (1956) : FitzGerald's Salámán and Absal : A Study, London, Cambridge UP.

ARBERRY, Arthur J. (1952): Omar Khayyám : A New Version Based upon Recent Discoveries, New Haven, Yale UP.

ARBERRY, Arthur J. (1959): The Romance of Rubáivát: FitzGerald's First Edition Reprinted with Introduction and Notes, London, Allen and Unwin.

AVERY, Peter (1973): Preface, Translation or Travesty? An Enquiry into Robert Graves' Version of Some Rubaiyat of Omar Khayyam, by J. C. E. Bowen, Abingdon, The Abbey Press.

AVERY, Peter and John HEATH-STUBBS (1981): The Ruba iyat of Omar Khayyam, 1979, New York, Penguin Books.

BOWEN, John Charles Edward (1974) : "The Ruba iyyat of Omar Khayyam : A Critical Assessment of Robert Graves and Omar Ali-Shah's Translation," Iran 11, pp. 63-73.

BOWEN, John Charles Edward (1973): Translation or Travesty? An Enquiry into Robert Graves's Version of Some Rubaiyat of Omar Khayyam, Abingdon, The Abbey Press.

BROWNE, Edward G. (1902) : A Literary History of Persia, 4 vols., London, T. Fisher Unwin, 1902.

CHRISTENSEN, Arthur (1927) : Critical Studies in the Rubá 'ýát of 'Umar-i-Khayyám, Copenhagen, Host.

DASHTI, Ali (1971): In Search of Omar Khayyam, trans. L. P. Elwell-Sutton, London, George Allen \& Unwin Ltd.

ELWELL-SUTTON, L. P. (1968) : "The Omar Khayyam Puzzle," Royal Central Asian Journal, 55 :2, pp. 167179.

ELWELL-SUTTON, L. P. (1969) : “The Rubaiyat Revisited," Delos, 3, pp. 170-191.

FITZGERALD, Edward (1952): The Rubáiyát of Omar Khayyám, New York, Doubleday.

GRAVES, Robert and Omar ALI-SHAH (1967): The Rubaiyyat of Omar Khayyam: A New Translation with Critical Commentaries, London, Cassell.

HERON-ALLEN, Edward (1899): Edward FitzGerald's Rubaiyat of Omar Khayyam, London, Bernard Quatritch.

MINORSKI, Vladimir (1967): "The Earliest Collections of O. Khayyam," Yádnáme-ye Jan Rypka, Prague, Academia, pp. 107-118.ROSEN, Friedrich (1930): The Quatrains of 'Omar Khayyám, London, Methuen \& Co. Ltd.

SCHEKNER, Daniel (1981): "Fugitive Articulation: An Introduction to The Rubáiyát of Omar Khayyám," Victorian Poetry, 18, pp. 49-64.

TERHUNE, Alfred McKinley, ed. (1980): The Letters of Edward FitzGerald, 4 vols., Princeton, New Jersey, Princeton UP.

TERHUNE, Alfred McKinley, ed. (1947): The Life of Edward FitzGerald, New Haven, Yale University Press.

TIRTHA, Swami Govinda (1941): The Nectar of Grace, Allahabad, Kitabistan.

ZHUKOVSKY, V. A. (1898): "The Wandering Quatrains of Omar Khayyam," trans. E. D. Ross, Journal of the Royal Asiatic Society, 30, pp. 349-366. 